\title{
Effect of Nature of Explants and its Orientation on Shoot Establishment in Kufri Bahar and Kufri Surya Varieties of Potato (Solanum tuberosum L.) for Micropropagation
}

\author{
Deven Verma ${ }^{*}$, A.C. Yadav $^{2}$ and N.R. Yadav \\ ${ }^{1}$ Division of Vegetable Crops, ICAR-Indian Institute of Horticultural Research, Bengaluru \\ (560089), Karnataka, India \\ ${ }^{2}$ Department of Vegetable Science, ${ }^{3}$ Department of Molecular Biology and Biotechnology, \\ CCSHAU, Hisar (125004), Haryana, India \\ *Corresponding author
}

\section{A B S T R A C T}

K e y w o r d s
Potato, Surface
sterilization,
Micropropagation,
Sprouts, Nodal
cuttings,
Orientation, MS
media

\section{Introduction}

The yield of potato crop depends upon numerous factors like environmental conditions during growth, agronomic practices, genetic yield potential and health of seed tubers. Among all the above mentioned reasons, use of healthy seed tubers is the most vital factor, because potato crop is being propagated asexually. However, all the
The experiment was conducted to study the effect of nature of explants and its orientation on shoot establishment over MS media in Kufri Bahar and Kufri Surya cultivars of potato under in vitro conditions. The results indicated that a combination of $0.4 \%$ Bavistin $(25$ $\min )+0.1 \% \mathrm{HgCl}_{2}(30 \mathrm{sec})$ provided the maximum number of aseptic explants $(73.33 \%)$. The results have shown that in Kufri Bahar 69.18 per cent sprouts produced shoots with higher number of shoots/explant. While in case of Kufri Surya sprout's bits responded very well $(90.00 \%)$ and sprouts have produced more number of shoots/explant (6.00), average number of nodes/explants $(5.12)$ and average shoot length $(6.38 \mathrm{~cm})$. The results have further shown that orienting of explants vertically, significantly increased the per cent establishment of explants (75.68\% in Kufri Bahar and 70.78\% in Kufri Surya), whereas, the average number of shoots, average number of nodes per explants and average shoot length was found to be more in case of horizontal orientation of explants over the media. 
are spread through seed tubers and pose a grave threat to potato seed production. Thus, non-availability of quality and disease free seed tubers in adequate amount is the major hindrance in potato cultivation. The problem is further made worse by high seed rate due to which the cost of seed potatoes alone accounts for about 40 to 60 per cent of the total production costs in many parts of the world (Shekhawat et al., 1997).

Several factors have been reported which influence in vitro plant growth viz., nature of explants, explant orientation, culture media, hormones, temperature, humidity, among other factors (Rani et al., 2013; Jainol and Gansau, 2016; Morais et al., 2018).

Keeping the above points in mind the experiment was conducted to study the effect of nature of explants and its orientation on shoot establishment for micropropagation in Kufri Bahar and Kufri Surya under in vitro conditions.

\section{Materials and Methods}

\section{Plant materials}

The required tubers of the two potato cultivars Kufri Surya and Kufri Bahar were collected from the farm of Department of Vegetable Science, CCS Haryana Agricultural University, Hisar. Eyes, single node cuttings, shoot tips, nodal explants, sprouts and bits of sprouts were used as explants for growing in vitro shoot cultures. Nodal explants were taken from field grown plants.

\section{Orientation}

Explants were placed vertically as well as horizontally over the media surface to study the effect of orientation and its interaction with nature of explants.

\section{Surface sterilisation}

Explants were washed in running tap water and then washed again thoroughly by adding a few drops of Teepol, a mild soap solution. Afterwards, the explants were treated with different combinations of disinfectant chemicals viz., mercuric chloride, $70 \%$ ethanol, Bavistin and potassium permanganate. After the surface sterilization of the explants they were thoroughly rinsed 45 times using double distilled and autoclaved water.

\section{Media}

The MS (Murashige and Skoog, 1962) medium was used for shoot establishment studies. Sucrose $(3 \% \mathrm{w} / \mathrm{v})$ and myo-inositol were added and dissolved. The volume was made up to one litre using distilled water and the $\mathrm{pH}$ of the medium was adjusted to 5.8 using $1 \mathrm{~N} \mathrm{NaOH}$ or $1 \mathrm{~N} \mathrm{HCl}$. Agar $(0.8 \%)$ was added in the medium, melted in microwave and thoroughly mixed.

Also during the experiment, readymade MS media (Hi-Media Biosciences) was used which was only short of sucrose and agar, which were accordingly mixed into the media during its preparation.

\section{Incubation of culture}

The inoculated cultures were incubated at $25 \pm 2{ }^{\circ} \mathrm{C}$ in an air-conditioned culture room with a light intensity of 2000-3000 lux by cool white fluorescent tubes. The lights per dark cycles of photoperiod were maintained as 16 per 8 hours daily.

\section{Traits studied}

The traits studied were per cent of explants established, number of shoots/explants, number of nodes/explants and shoot length (cm). 


\section{Experimental design}

For in vitro micropropagation study a factorial experiment consisting of combinations of cultivars, nature of explants and explants' orientation was conducted using a factorial CRD. Each treatment combination was replicated three times, where each replication consisted of a culture vessel having 7-8 explants. Thus, there were 21-25 plantlets per cultivar per treatment.

\section{Data analysis}

The data recorded on various characteristics were analyzed statistically. Analysis of variance (ANOVA) was performed using a computer statistical analysis programme (OPSTAT). To judge the significant difference between means of two treatments, the critical difference (C.D.) was used.

\section{Results and Discussion}

\section{Surface sterilization of explants}

Disinfection treatments involving Teepol, Bavistin, mercuric chloride, ethyl alcohol and potassium permanganate were used for the surface sterilization of the explants. In all the trials all the explants were first washed thoroughly with Teepol, and then subjected to different sterilization treatments (as tabulated in Table 1), afterwards explants were washed 3-4 times with autoclaved double distilled water.

For disinfection of explants in both the varieties (i.e., Kufri Surya and Kufri Bahar) $\mathrm{T}_{7}$ was found to be the best as it yielded over 73 per cent sterile explants.

Effect of different types of explants on in vitro shoot establishment in Kufri Bahar and Kufri Surya

Three different types of explants viz. sprouts, multiple nodal cuttings and single nodal cuttings, were used for the establishment of shoots in Kufri Bahar; and for in vitro shoot establishment studies in Kufri Surya, six types of explants, viz., sprouts, eyes from potato tubers, nodal cuttings from field grown plants, multiple nodal cuttings, single nodal cuttings and sprout's bits, were used (Table 2). Sprouts when used as explants in Kufri Bahar showed promising results as 69.18 per cent of the explants were able to establish shoots and the average number of shoots produced on them was 4.33 / explant having an average length of $5.99 \mathrm{~cm}$ consisting of 4.79 nodes per shoot.

Whereas, for Kufri Surya highest shoot establishment was found in case of sprouts' bits $(90.00 \%)$, which was at par with per cent shoot establishment from sprouts $(83.85 \%)$, minimum response from explants was obtained when eyes from tubers were used as explants (47.39\%). Average number of shoots produced per explants was significantly higher in case of sprouts (6.00), followed by multiple nodal cuttings (3.13). Minimum numbers of shoots were formed when sprouts' bits were used as explants (1.07). Maximum number of nodes per explant was observed in shoots obtained from multiple nodal cuttings (5.68), whereas, minimum were noticed in shoots obtained from single nodal cuttings (4.27). Longest shoots $(6.38 \mathrm{~cm})$ were obtained from sprouts, followed by shoots obtained from single nodal cuttings $(5.47 \mathrm{~cm})$; shortest shoots were obtained from sprouts' bits (4.88 $\mathrm{cm})$.

\section{Effect of explant's orientation on shoot establishment in Kufri Bahar and Kufri Surya}

The explants were placed horizontally and vertically over the media surface to study the effect of orientation of explants on in vitro shoot establishment. It can clearly be noticed from Table 3 that in both the varieties orienting of explants vertically, significantly increased the per cent establishment of 
explants (75.68 and 70.78\%), whereas, the average number of shoots, average number of nodes per explants and average shoot length was found to be more in case of horizontal orientation of explants over the media.

Effect of nature of explants and its orientation on shoot establishment in Kufri Bahar and Kufri Surya

Effect of nature of explants (i.e., sprouts, multiple nodal cuttings and single nodal cuttings), their orientation (viz., horizontal and vertical) over the media surface and interaction between the above two factors was studied in Kufri Bahar and Kufri Surya for in vitro shoot establishment studies. The results, thus, obtained are as under:

\section{On per cent regeneration}

In Kufri Bahar and Kufri Surya cultivars there was no significant interaction between the nature and orientation of explants with regard to per cent regeneration of explants. The results depicted in Table 4 shows that vertical placement of Kufri Bahar explants over the media had slightly higher per cent regeneration of explants $(67.89 \%)$ as compared to their horizontal placement $(66.08 \%)$. When single nodal cuttings were used as explants for in vitro shoot establishment highest per cent regeneration was noticed $(75.0 \%)$. However, per cent regeneration of explants was highest in case of horizontal placement of single nodal cuttings $(75.98 \%)$.

In Kufri Surya the vertically placed explants, irrespective of their nature, resulted in higher percentage of shoot establishment (82.82) as compared to those placed horizontally $(70.42 \%)$. Per cent response of multiple nodal cuttings $(81.91 \%)$ was more as compared to single nodal cuttings (74.49\%) and sprouts (73.46\%). There was no significant interaction between the nature and orientation of explants, however, the highest response was found in case of multiple nodal cuttings when placed vertically $(83.09 \%)$.

\section{On number of shoots per explants}

There was no significant interaction between the explant's orientations (i.e. horizontal or vertical) and their nature on number of shoots produced per explants in Kufri Surya cultivar of potato, however, in case of Kufri Bahar the interaction was found to be affecting the trait under study (Table 4). Number of shoots obtained from sprouts was highest in both the cultivars (3.16 and 4.53) and single nodal cuttings produced least number of shoots per explants (1.23 and 1.47).

\section{On shoot length}

There was no significant interaction found between the nature of explants and their orientations, in regard to shoot length as observed in Kufri Bahar and Kufri Surya (Table 4).

In Kufri Bahar placement of explants horizontally produced longer plantlets (4.62 $\mathrm{cm})$, as compared to vertically placed explants $(3.95 \mathrm{~cm})$. Mean length of plantlets produced by sprouts $(4.96 \mathrm{~cm})$ was more as compared to the other two explants. Longest plantlets were obtained when sprouts were placed horizontally $(5.23 \mathrm{~cm})$ and shortest were observed in case of single nodal cuttings when placed vertically $(3.35 \mathrm{~cm})$.

In Kufri Surya longer plants were produced when explants were placed vertically (5.43 $\mathrm{cm})$ (Table 4). Sprouts when used as explants for establishment of in vitro shoot cultures, produced longer plantlets $(5.84 \mathrm{~cm})$, as compared to multiple nodal cuttings $(5.28 \mathrm{~cm})$ and single nodal cuttings $(4.48 \mathrm{~cm})$. Longest plantlets were obtained when sprouts were placed vertically $(6.19 \mathrm{~cm})$ and shortest were observed in case of single nodal cuttings when placed vertically $(4.47 \mathrm{~cm})$. 
Table.1 Effect of various treatments used for surface sterilization of explants on percentage of sterile explants obtained

\begin{tabular}{|l|l|c|}
\hline Code & Disinfection procedure & \% sterile explants \\
\hline $\mathbf{T}_{\mathbf{1}}$ & $0.3 \%$ Bavistin $(30 \mathrm{~min})+0.2 \% \mathrm{HgCl}_{2}(1 \mathrm{~min})$ & 40.00 \\
\hline $\mathbf{T}_{\mathbf{2}}$ & $0.3 \%$ Bavistin $(30 \mathrm{~min})+0.2 \% \mathrm{HgCl}_{2}(30 \mathrm{sec})$ & 62.50 \\
\hline $\mathbf{T}_{\mathbf{3}}$ & $0.3 \%$ Bavistin $(30 \mathrm{~min})+0.1 \% \mathrm{HgCl}_{2}(6 \mathrm{~min})$ & 20.00 \\
\hline $\mathbf{T}_{\mathbf{4}}$ & $0.4 \%$ Bavistin $(25 \mathrm{~min})+0.1 \% \mathrm{HgCl}_{2}(4 \mathrm{~min})$ & 25.00 \\
\hline $\mathbf{T}_{\mathbf{5}}$ & $0.4 \%$ Bavistin $(25 \mathrm{~min})+0.1 \% \mathrm{HgCl}_{2}(2 \mathrm{~min})$ & 30.00 \\
\hline $\mathbf{T}_{\mathbf{6}}$ & $0.4 \%$ Bavistin $(25 \mathrm{~min})+0.1 \% \mathrm{HgCl}_{2}(1 \mathrm{~min})$ & 63.33 \\
\hline $\mathbf{T}_{\mathbf{7}}$ & $0.4 \%$ Bavistin $(25 \mathrm{~min})+0.1 \% \mathrm{HgCl}_{2}(30 \mathrm{sec})$ & 73.33 \\
\hline $\mathbf{T}_{\mathbf{8}}$ & $0.4 \%$ Bavistin $(25 \mathrm{~min})+70 \%{\mathrm{ethanol} \mathrm{dip}+0.1 \% \mathrm{HgCl}_{2}(1 \mathrm{~min})}_{55.00}$ \\
\hline $\mathbf{T}_{\mathbf{9}}$ & $0.4 \%$ Bavistin $(25 \mathrm{~min})+0.2 \% \mathrm{KMnO}_{4}(10 \mathrm{~min})$ & 0.00 \\
\hline
\end{tabular}

Table.2 Effect of different types of explants on in vitro shoot establishment in Kufri Bahar and Kufri Surya

\begin{tabular}{|c|c|c|c|c|c|}
\hline Variety & $\begin{array}{l}\text { Type of } \\
\text { explant }\end{array}$ & $\begin{array}{l}\text { Per cent explants } \\
\text { responded }(\%)\end{array}$ & $\begin{array}{c}\text { Average number of } \\
\text { shoots/explants }\end{array}$ & $\begin{array}{c}\text { Average number of } \\
\text { nodes/explant }\end{array}$ & $\begin{array}{c}\text { Average shoot } \\
\text { length }(\mathrm{cm})\end{array}$ \\
\hline \multirow{5}{*}{$\begin{array}{l}\text { Kufri } \\
\text { Bahar }\end{array}$} & Sprouts & 69.18 & 4.33 & 4.79 & 5.99 \\
\hline & $\begin{array}{l}\text { Multiple Nodal } \\
\text { Cuttings }\end{array}$ & 55.64 & 3.12 & 4.66 & 5.62 \\
\hline & $\begin{array}{l}\text { Single Nodal } \\
\text { Cuttings }\end{array}$ & 60.68 & 1.20 & 3.73 & 4.05 \\
\hline & Mean & 61.83 & 2.88 & 4.39 & 5.22 \\
\hline & $C D(p=0.05)$ & 6.40 & 0.58 & 0.62 & 0.68 \\
\hline \multirow{8}{*}{$\begin{array}{l}\text { Kufri } \\
\text { Surya }\end{array}$} & Sprouts & 83.85 & 6.00 & 5.12 & 6.38 \\
\hline & Eyes & 47.39 & 1.60 & 4.68 & 5.21 \\
\hline & Nodal explants & 63.70 & 1.60 & 5.14 & 5.29 \\
\hline & $\begin{array}{l}\text { Multiple Nodal } \\
\text { Cuttings }\end{array}$ & 67.21 & 3.13 & 5.68 & 5.25 \\
\hline & $\begin{array}{l}\text { Single Nodal } \\
\text { Cuttings }\end{array}$ & 74.23 & 1.20 & 4.27 & 5.47 \\
\hline & Sprouts' Bits & 90.00 & 1.07 & 4.73 & 4.88 \\
\hline & Mean & 71.06 & 2.43 & 4.94 & 5.41 \\
\hline & $C D(p=0.05)$ & 14.17 & 0.37 & 0.54 & 0.81 \\
\hline
\end{tabular}


Table.3 Effect of explant's orientation on shoot establishment in Kufri Bahar and Kufri Surya

\begin{tabular}{|c|c|c|c|c|c|}
\hline Variety & Orientation & $\begin{array}{l}\text { Per cent explants } \\
\text { responded }(\%)\end{array}$ & $\begin{array}{l}\text { Average number } \\
\text { of Shoots/ explants }\end{array}$ & $\begin{array}{c}\text { Average } \\
\text { number of } \\
\text { nodes/ shoot }\end{array}$ & $\begin{array}{c}\text { Average shoot } \\
\text { length }(\mathrm{cm}) / \mathrm{shoot}\end{array}$ \\
\hline \multirow{4}{*}{$\begin{array}{l}\text { Kufri } \\
\text { Bahar }\end{array}$} & Horizontal & 54.87 & 2.32 & 4.50 & 5.09 \\
\hline & Vertical & 75.68 & 1.97 & 4.46 & 4.82 \\
\hline & Mean & 65.28 & 2.14 & 4.49 & 4.89 \\
\hline & $\mathrm{CD}(\mathrm{p}=0.05)$ & 20.94 & NS & NS & NS \\
\hline \multirow{4}{*}{$\begin{array}{l}\text { Kufri } \\
\text { Surya }\end{array}$} & Horizontal & 65.06 & 3.17 & 6.49 & 5.82 \\
\hline & Vertical & 70.78 & 2.27 & 4.70 & 6.97 \\
\hline & Mean & 67.92 & 2.72 & 5.6 & 6.39 \\
\hline & $C D(p=0.05)$ & 3.19 & 0.56 & NS & 0.92 \\
\hline
\end{tabular}

Table.4 Effect of nature of explants and its orientation on shoot establishment in Kufri Bahar and Kufri Surya

\begin{tabular}{|c|c|c|c|c|c|c|c|c|c|c|}
\hline \multirow{4}{*}{$\begin{array}{l}\text { Variety } \\
\text { Kufri } \\
\text { Bahar }\end{array}$} & \multirow[t]{3}{*}{ Explant } & \multicolumn{3}{|c|}{ Per cent regeneration } & \multicolumn{3}{|c|}{ Number of shoots/explant } & \multicolumn{3}{|c|}{ Average shoot length $(\mathrm{cm})$} \\
\hline & & \multicolumn{2}{|c|}{ Orientation } & \multirow[t]{2}{*}{ Mean } & \multicolumn{2}{|c|}{ Orientation } & \multirow[t]{2}{*}{ Mean } & \multicolumn{2}{|c|}{ Orientation } & \multirow[t]{2}{*}{ Mean } \\
\hline & & Horizontal & Vertical & & Horizontal & Vertical & & Horizontal & Vertical & \\
\hline & Sprouts & 59.19 & 63.07 & 61.13 & 3.38 & 2.93 & 3.16 & 5.23 & 4.69 & 4.96 \\
\hline & MNCs & 63.07 & 66.58 & 64.83 & 2.27 & 2.80 & 2.53 & 4.59 & 3.81 & 4.20 \\
\hline & SNCs & 75.98 & 74.02 & 75.00 & 1.20 & 1.27 & 1.23 & 4.06 & 3.35 & 3.70 \\
\hline & Mean & 66.08 & 67.89 & & 2.28 & 2.33 & & 4.62 & 3.95 & \\
\hline & $\begin{array}{l}\text { CD } \\
(p=0.05)\end{array}$ & \multicolumn{3}{|c|}{$\begin{array}{c}\text { Orientation }(\mathrm{O})=\mathrm{NS} \\
\text { Nature of explant }(\mathrm{N})= \\
11.07 \\
\mathrm{O} \times \mathrm{N}=\mathrm{NS}\end{array}$} & \multicolumn{3}{|c|}{$\begin{array}{c}\text { Orientation }(\mathrm{O})=\mathrm{NS} \\
\text { Nature of explant }(\mathrm{N})=0.36 \\
\mathrm{O} \times \mathrm{N}=0.51\end{array}$} & \multicolumn{3}{|c|}{$\begin{array}{c}\text { Orientation }(O)=0.32 \\
\text { Nature of explant }(\mathrm{N})=0.39 \\
O \times N=\mathrm{NS}\end{array}$} \\
\hline \multirow{5}{*}{$\begin{array}{l}\text { Kufri } \\
\text { Surya }\end{array}$} & Sprouts & 64.23 & 82.68 & 73.46 & 4.47 & 4.60 & 4.53 & 5.49 & 6.19 & 5.84 \\
\hline & MNCs & 80.73 & 83.09 & 81.91 & 3.13 & 3.27 & 3.20 & 4.94 & 5.63 & 5.28 \\
\hline & SNCs & 66.29 & 82.68 & 74.49 & 1.47 & 1.47 & 1.47 & 4.49 & 4.47 & 4.48 \\
\hline & Mean & 70.42 & 82.82 & & 3.02 & 3.11 & & 4.97 & 5.43 & \\
\hline & $\begin{array}{l}\text { CD } \\
(p=0.05)\end{array}$ & \multicolumn{3}{|c|}{$\begin{array}{c}\text { Orientation }(O)=10.53 \\
\text { Nature of explant }(N)=N S \\
O \times N=N S\end{array}$} & \multicolumn{3}{|c|}{$\begin{array}{c}\text { Orientation }(\mathrm{O})=\mathrm{NS} \\
\text { Nature of explant }(\mathrm{N})=0.38 \\
O \times N=\mathrm{NS}\end{array}$} & \multicolumn{3}{|c|}{$\begin{array}{c}\text { Orientation }(O)=0.38 \\
\text { Nature of explant }(\mathrm{N})=0.46 \\
O \times N=N S\end{array}$} \\
\hline
\end{tabular}

\section{Surface sterilization of explants}

For establishment of in vitro shoot culture of both the potato varieties different types of explants were used which were surface sterilized by the different combinations of chemical agents. Out of all the treatments used, treatment $\mathrm{T}_{7}[0.4 \%$ Bavistin (25 min.) + $0.1 \% \mathrm{HgCl}_{2}(30 \mathrm{sec}$.)] was found to be the best with over 73 per cent sterilized explants. In addition to sterilization of explants with alcohol and mercuric chloride, Bavistin was tried to control the fungal contamination in potato (Singh et al., 2017).

\section{Nature of explants}

Shoot apices, axillary buds, sprouts, single nodal cuttings and tuber eyes have been earlier used as explants for initiating shoot cultures by various researchers (Mingo-Castel et al., 1976; Bhutani, 1996; Dutra et al., 2010; 
Rocha et al., 2015; Ali et al., 2018; Silva Filho et al., 2018).

Thus, during the experiment sprouts, multiple nodal cuttings and single nodal cuttings were used as the explants in Kufri Bahar for the same. Out of them, sprouts were found to be better followed by the single nodal cuttings. Also the average number of shoots produced per explant was higher in case of sprouts.

Similarly, in case of Kufri Surya six types of explants, viz., sprouts, eyes from potato tubers, nodal cuttings from field grown plants, multiple nodal cuttings, single nodal cuttings and sprout's bits, were used. The results in Kufri Surya showed that eyes from potato tubers should not be used as explants, while sprouts and bits of sprouts can easily be used for production of plantlets over the media.

\section{Orientation of explants}

The effect of explant's orientation over the media surface was reported by many researchers on micropropagation of potato (Mng'omba et al., 2017; Buckseth et al., 2018).

Orienting of explants vertically, significantly increased the per cent establishment of explants (75.68 and $70.78 \%$ ), whereas, the average number of shoots, average number of nodes per explants and average shoot length was found to be more in case of horizontal orientation of explants over the media.

\section{Interaction between nature of explants and their orientation on shoot establishment}

In both the cultivars of potato there was no significant effect of interaction between the nature and orientation of explants with regard to per cent regeneration of explants and average shoot length. There was no significant effect of interaction between the nature and orientation of explants with regard to number of shoots produced per explants in Kufri Surya; but in case of Kufri Bahar this trait was found to be affected by the interaction of the explants' nature and their orientation (as confirmed by Buckseth et al., 2018), which means that, sprouts when used as explants placed horizontally over the media would produce significantly higher number of shoots per explant.

\section{Acknowledgement}

It is my privilege to express my deepest sense of gratitude and sincere thanks to all the teaching as well as non teaching faculty of Department of Vegetable Science as well as Department of Molecular Biology and Biotechnology, CCS Haryana Agricultural University, Hisar, Haryana for providing me all the facilities and the tubers of both the cultivars of potato required for conducting the experiment.

\section{References}

Ali, S., Khan, N., Nouroz, F., Erum, S., Nasim, W., and Shahid, M. A. 2018. In vitro effects of GA3 on morphogenesis of CIP potato explants and acclimatization of plantlets in field. In Vitro Cellular and Developmental Biology Plant. 54(1), 104-111.

Bhutani, S. 1996. Studies on in vitro shoot multiplication and microtuberisation in potato (Solanum tuberosum L.). M. Sc. Thesis. CCS Haryana Agricultural University, Hisar, India.

Buckseth, T., Singh, R. K., Sharma, A. K., Sharma, S., Moudgil, V., and Saraswati, A. 2018. Influence of Node Number and Orientation of Explants on in Vitro Growth and Development of Potato. Cytologia. 83(1), 19-22.

Dutra, L. F., Mayer, K. C. de A., da Silva, N. D. G., Nino, A. F. P., da Silva, F. O. X., 
and Vieira, F. C. B. 2010. Protocolos de Micropropagação de Plantas. I - Batata. Pelotas: Embrapa Clima TemperadoDocumentos (INFOTECA-E).

Jainol, J. E., and Gansau, J. A. 2016. Effect of growth regulators and explant orientation on shoot tip culture of borneo endemic orchid, Dimorphorchis lowii. Transactions on Science and Technology. 3(2), $306-312$.

Mingo-Castel, A. M., Young, R. E., and Smith, O. E. 1976. Kinetin-induced tuberization of potato in vitro: on the mode of action of kinetin. Plant and Cell Physiology. 17(3), 557-570.

Mng'omba, S. A., Mwale, H., Chimzinga, B., Longwe, K., and Muhota, P. 2017. In vitro potato (Solanum tuberosum L.) growth under different orientation and light/dark exposure conditions. African Journal of Biotechnology. 16(34), 17841790.

Morais T. P. de, Asmar S. A., Silva H. F. de J., Luz J. M. Q., Melo B. 2018. Application of tissue culture techniques in potato. Bioscience Journal Uberlândia. 34(4), 952-969.

Murashige, T., and Skoog, F. 1962. A revised medium for rapid growth and bioassays with tobacco tissue cultures. Journal of Plant Physiology. 15, 473-479.
Rani, T., Yadav, R. C., Yadav, N. R., and Kumar, M. 2013. Effect of explant orientation on shoot regeneration in tomato (Lycopersicon esculentum). Indian Journal of Agricultural Science. 83(5), 514-517.

Rocha, P. S. G. da, Oliveira, R. P. de, and Scivittaro, W. B. 2015. New light sources for in-vitro potato micropropagation. Bioscience Journal Uberlândia. 31(5), 1312-1318.

Shekhawat, G.S., Gaur, P.C., Naik, P.S., and Sarkar, D. $1997 . \quad$ Potato micropropagation: Commercial prospects in India. In National Conference on transgenics, Tissue Culture and Floriculture. All India Biotech Association, New Delhi, India. 24-32.

Silva, F. J. B., Fontes, P. C. R., Cecon, P. R., Mcgiffen, Jr. M. E. 2018. Evaluation of "UFV Aeroponic System" to produce basic potato seed minitubers. American Journal of Potato Research. 95(5), 443450.

Singh, A.K., Sharma, M. K., and Sengar, R. S. 2017. High frequency in vitro callus induction in potato (Solanum tuberosum L.) Genotypes. International Journal of Chemical Studies. 5(5), 1294-1297.

\section{How to cite this article:}

Deven Verma, A.C. Yadav and Yadav, N.R. 2018. Effect of Nature of Explants and its Orientation on Shoot Establishment in Kufri Bahar and Kufri Surya Varieties of Potato (Solanum tuberosum L.) for Micropropagation. Int.J.Curr.Microbiol.App.Sci. 7(12): 10051012. doi: https://doi.org/10.20546/ijcmas.2018.712.125 